\title{
SISTEM INFORMASI PERIKANAN TANGKAP D.I. YOGYAKARTA: PENGEMBANGAN BASIS DATA LINGKUNGAN, PRODUKSI, DAN SISTEM KEPUTUSAN PENANGKAPAN IKAN
}

\section{The Information Systems of Capture Fisheries in D.I. Yogyakarta: Development of Environmental Databases, Production, and Fish Catching Decision Systems}

\author{
Oleh: \\ Mustaruddin ${ }^{1 *}$, Asnil ${ }^{2}$, dan Angga Nugraha ${ }^{3}$ \\ ${ }^{1}$ Departemen Pemanfaatan Sumberdaya Perikanan, FPIK \\ IPB, Bogor \\ ${ }^{2}$ Badan Nasional Pengelola Perbatasan (BNPP) RI, Jakarta \\ ${ }^{3}$ Sofware House Park, Bogor \\ *Korespondensi penulis: mus_m03@yahoo.com
}

\begin{abstract}
ABSTRAK
Sistem informasi perikanan tangkap membantu Pemerintah D.I. Yogyakarta dalam pembangkitan ekonomi dan pengambilan kebijakan perikanan. Penelitian ini bertujuan merancang sistem informasi yang memuat sistem basis data dan sistem pengambilan keputusan perikanan tangkap. Penelitian dilaksanakan pada bulan November 2017-April 2018 di D.I Yogyakarta. Metode yang digunakan adalah perumusan DFD, pemprograman, dan perancangan sistem informasi. Sistem informasi yang dirancang bernama 'Sistem Informasi Manajemen Perikanan Tangkap D.I. Yogyakarta' (SIM Perikanan Tangkap DIY). Hasil rancangan sistem informasi ini memuat 2 (dua) sistem basis data (lingkungan perairan dan produksi perikanan) dan 1 (satu) sistem pengambilan keputusan. Menu-menu penting yang telah diintegrasikan pada sistem basis data lingkungan perairan diantaranya menu klorofil, SPL, terumbu karang, dan oseanografi perairan, sedangkan pada sistem basis data produksi perikanan diantaranya menu DPI, potensi upwelling, potensi SDI, musim ikan, jumlah produksi, nilai produksi, dan kinerja usaha penangkapan ikan. Sistem pengambilan keputusan (SPK) dirancang untuk mengolah data penting pada kedua basis data. SPK ini memuat menu analisis/perhitungan seperti analisis potensi SDI, analisis moving average, analisis musim, dan analisis kelayakan usaha.
\end{abstract}

Kata kunci: basis data, D.I. Yogyakarta, lingkungan, produksi perikanan, sistem informasi

\section{ABSTRACT}

Information system of capture fisheries helps the Government of D.I. Yogyakarta in economic generation and fisheries policy making. This research aimed to design an information system that includes database systems and a capture fisheries decision-making system. The research was conducted from November 2017 to April 2018 in D.I. Yogyakrata. This research used DFD formulation, programming, and information system design. The information system designed was called the 'Capture Fisheries Management Information System in D.I. Yogyakarta'. This information system contained 2 (two) database systems (environmental database and fishery production database) and 1 (one) decision making system. The important menus that had been integrated into environmental database system include the menu of chlorophyll, SST, coral reefs, and marine oceanography, while fisheries production database system include the menu of fishing ground, upwelling, fish resources potential, fish season, production amount, production value, and fishing business performance. The decision making system (DSS) was designed to process the important data on both databases. This DSS 
contained analysis/calculation menus such as fish potential analysis, moving average analysis, season analysis, and business feasibility analysis.

Key words: database, D.I. Yogyakarta, environment, fisheries production, information systems

\section{PENDAHULUAN}

Sektor kelautan dan perikanan memiliki potensi besar sebagai katalisator dan dinamisator pembangunan perekonomian di Indonesia. Hal ini dominan karena perairan laut Indonesia yang luas yang menyimpan sumberdaya ikan yang begitu melimpah dan hampir semuanya mempunyai nilai ekonomis yang tinggi dan dibutuhkan pasar global. Pemanfaatan sumberdaya ikan tersebut akan menggerakkan kegiatan ekonomi lainnya baik yang bertumpu pada penyediaan perbekalan melaut, pengolahan pasca panen hasil perikanan, transportasi perikanan, usaha pendukung dan jasa lainnya. Penggiatan perekonomian seperti ini sangat dibutuhkan dibanyak daerah di Indonesia terutama yang lahan daratannya tidak terlalu luas, sementara jumlah penduduk terus bertambah dan lapangan kerja yang semakin terbatas. Salah satu daerah yang mencoba mengembangkan sektor kelautan dan perikanan sebagai penggerak pembangunan perekonomiannya adalah D.I. Yogyakarta.

Menurut DKP DIY (2018) dan Rahmi et al. (2013), pengembangan ekonomi di sektor kelautan dan perikanan D.I. Yogyakarta diprioritaskan pada sub sektor perikanan tangkap yaitu dengan mengoptimalkan pemanfaatan sumberdaya ikan yang terdapat di perairan laut D.I. Yogyakarta. Upaya ini dilakukan dengan berbagai cara, salah satunya dengan menjadikan pelabuhan/pangkalan pendaratan ikan sebagai basis pertumbuhan ekonomi perikanan. Aksi nyata untuk melakukan hal ini adalah dengan pembenahan fasilitas fisik beberapa pelabuhan perikanan (BAPPEDA DIY 2019) dan pengembangan sistem informasi dan pendataan pendaratan ikan di pelabuhan/pangkalan pendaratan ikan. Pengembangan sistem informasi, diyakini mempunyai pengaruh besar bagi pertumbuhan ekonomi perikanan di D.I. Yogyakarta, karena informasi potensi, produksi, serta peluang investasinya dapat diakses masyarakat luas di berbagai penjuru terutama dari kalangan investor perikanan. Menurut Mustaruddin dan Wiyono (2020) dan Chuenpagdee et al. (2019), media sistem informasi terakses jauh lebih efektif mempublikasi data/informasi daripada yang disajikan dalam bentuk buku laporan, buku saku, bahkan event promosi khusus perikanan. Merkel dan Madsen (2019) dan Menard et al. (2002) menambahkan sistem informasi juga mempermudah penyimpanan dan pengolahan data, serta koordinasi antar lembaga di lingkungan pemerintahan terkait.

Memperhatikan hal tersebut, maka penelitian pengembangan sistem informasi perikanan tangkap dianggap penting untuk mendukung pembangkitan perekonomian sekaligus pendataan perikanan tangkap D.I. Yogyakarta yang lebih baik. Sistem informasi yang dikembangkan dalam penelitian ini, dilengkapi basis data dan sistem pengambilan keputusan yang mandiri, sehingga secara cepat bisa membantu pemerintah D.I. Yogyakarta dalam pengambilan kebijakan perikanan, investor dalam menjajaki peluang investasi perikanan, serta masyarakat luas yang berkepentingan dengan perikanan tangkap D.I. Yogyakarta. Penelitian ini bertujuan merancang sistem informasi yang memuat sistem basis data dan sistem pengambilan keputusan perikanan tangkap D.I. Yogyakarta.

\section{METODE PENELITIAN}

Penelitian ini dilaksanakan pada bulan November 2017-April 2018. Penelitian bertempat di D.I. Yogyakarta, dengan lokasi pengumpulan adalah delapan belas pelabuhan/pangkalan pendaratan ikan (fishing base) yang tersebar di sepanjang pesisir D.I. Yogyakarta. Data yang dikumpulkan dalam penelitian ini terdiri dari data klorofil-a, suhu permukaan laut (SPL), terumbu karang, oseanografi perairan, titik koordinat penangkapan ikan, potensi upwelling, trip melaut, sarana penangkapan dan kebutuhan investasinya, perbekalan, jumlah hasil tangkapan ikan, jenis ikan yang tertangkap, harga jual, dan lain-lain. Sebagian besar data tersebut dikumpulkan dengan melalui wawancara dan telaah 
pustaka terhadap berbagai laporan dan hasil studi terkait perikanan tangkap D.I. Yogyakarta. Untuk data klorofil-a dan suhu permukaan laut (SPL) diperoleh dengan mengunduh data citra satelit Aqua MODIS. Wawancara dilakukan secara purposive di setiap pelabuhan/pangkalan pendaratan ikan, yaitu petugas pendataan produksi ikan (1 orang) dan perwakilan nelayan ( 3 orang) yang aktif beraktivitas. Sedangkan pustaka yang ditelaah diantaranya laporan time series statistik perikanan tangkap D.I. Yogyakarta, hasil penelitian terumbu karang, dan hasil studi oseanografi perairan.

Ada tiga analisis yang dilakukan dalam penyusunan 'Sistem Informasi Perikanan Tangkap D.I. Yogyakarta' ini, yaitu perumusan data flow diagram (DFD), pemrograman, dan perancangan sistem informasi. DFD merupakan metode pemodelan yang ditujukan untuk menjelaskan lingkup dan keterkaitan dari komponen-komponen penyusunan suatu sistem informasi dan biasanya disajikan dalam bentuk diagram/alur tahapan (Chavance et al. 2007). Dalam penelitian ini, DFD melingkupi tiga komponen besar yang kemudian disebut sebagai menu utama. Ketiga menu utama tersebut yang diurut berdasarkan tahapan perancangannya adalah menu utama lingkungan perairan, menu utama produksi perikanan, dan menu utama sistem pengambilan keputusan (SPK).

Menu utama lingkungan perairan dan menu utama produksi perikanan dirancang sedemikian rupa agar dapat memeriksa, menyuplai, menyimpan semua data perikanan tangkap ke sistem informasi, baik data mentah maupun olahannya. Dalam konteks ini, kedua menu utama akan berperan sebagai basis data. Sedangkan menu utama SPK ditujukan untuk mengolah data ter-update dari dua menu utama lainnya menjadi informasi berguna untuk pengambilan kebijakan pengembangan perikanan tangkap D.I. Yogyakarta. Untuk hal ini, maka berbagai metode analisis terkait akan diintegrasikan pada menu utama SPK ini, diantaranya model Schaefer (untuk analisis potensi SDI), model moving average (untuk analisis musim ikan), aplikasi GIS, dan analisis kelayakan usaha (Maina et al. 2016, Hall dan Close 2007, Mayes dan Shank 2006).

Pemrograman dilakukan menggunakan bahasa pemrograman PHP. PHP adalah singkatan dari "Hypertext Preprocessor", yang merupakan sebuah bahasa scripting tingkat tinggi yang dipasang pada dokumen HTML (O'Brien dan Marakas 2011). Sebagian besar sintaks dalam PHP mirip dengan bahasa C, Java dan Perl, namun pada PHP ada beberapa fungsi yang lebih spesifik. Sedangkan tujuan utama dari penggunaan bahasa ini adalah untuk memungkinkan sistem informasi menerjemahkan DFD secara lebih dinamis dan dapat bekerja secara otomatis. Kelebihan penggunaan bahasa pemrograman PHP ini adalah kemampuannya dalam mengolah string yang kompleks dan memudahkan pengembangan sistem informasi dengan aplikasi web.

Setelah DFD disiapkan dan bahasa pemrograman dikuasai, maka dilakukan perancangan sistem informasi. Perancangan sistem informasi dilakukan dengan memperhatikan standar-standar sistem aplikasi yang baik, sehingga diperoleh efisiensi dan kemudahan dalam integrasi kompleksitas data, penggunaan kembali, dan pengubahannya sesuai kebutuhan yang diinginkan. Untuk itu, maka perancangan sistem informasi perikanan tangkap D.I. Yogyakarta ini, dilakukan dengan berpedoman pada tiga komponen sistem aplikasi terpisah (Chuenpagdee et al. 2019, O’Brien dan Marakas 2011), yaitu:

(1) User Interface: merupakan lapisan terdepan yang memfasilitasi pengguna dalam mengoperasikan sistem aplikasi.

(2) Business Rules. merupakan lapisan kedua yang mengakomodir aturan main dalam suatu proses analisis seperti perhitungan, validasi, dan lainnya.

(3) Data Access. merupakan lapisan ketiga yang mengelola mekanisme pengaksesan data di dalam suatu file basis data. 


\section{HASIL DAN PEMBAHASAN}

\section{Log Masuk dan Input Data Sistem Perikanan Tangkap D.I. Yogyakarta}

Sistem informasi yang disusun diberi nama 'Sistem Informasi Manajemen Perikanan Tangkap D.I. Yogyakarta' (SIM Perikanan Tangkap DIY). Untuk keamanan penggunaan, sistem informasi ini mensyaratkan setiap pengguna harus memiliki identitas akun (user id) dan kata sandi (password) untuk log masuk. SIM Perikanan Tangkap DIY terbagi dalam dua bagian yaitu bagian administrasi dan bagian analisis. Bagian administrasi dirancang sedemikian rupa agar dapat memeriksa dan meng-input data perikanan tangkap secara tepat pada SIM Perikanan Tangkap DIY. Bagian analisis ditujukan untuk mengolah data dari bagian administrasi (basis data lingkungan perairan dan basis data produksi perikanan) sehingga dapat dihasilkan sistem keputusan yang tepat bagi operasi penangkapan ikan di D.I. Yogyakarta. Gambar 1 menyajikan tampilan menu log masuk dan contoh fasilitas input data pada SIM Perikanan Tangkap DIY.

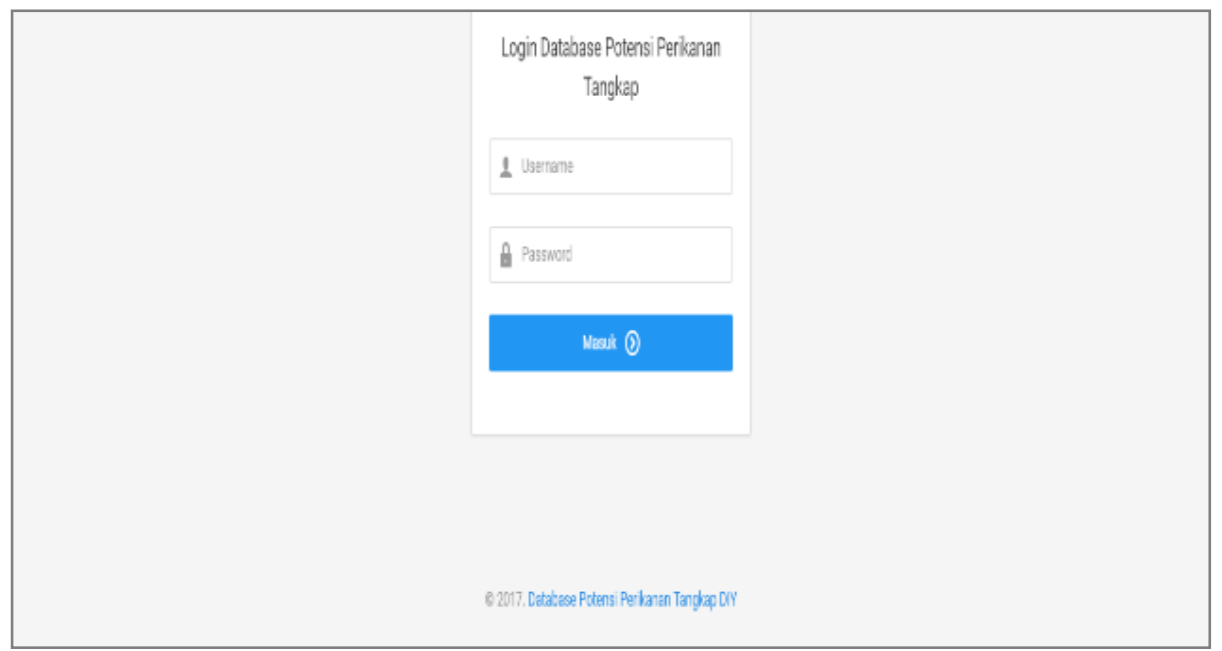

(a) Menu log masuk

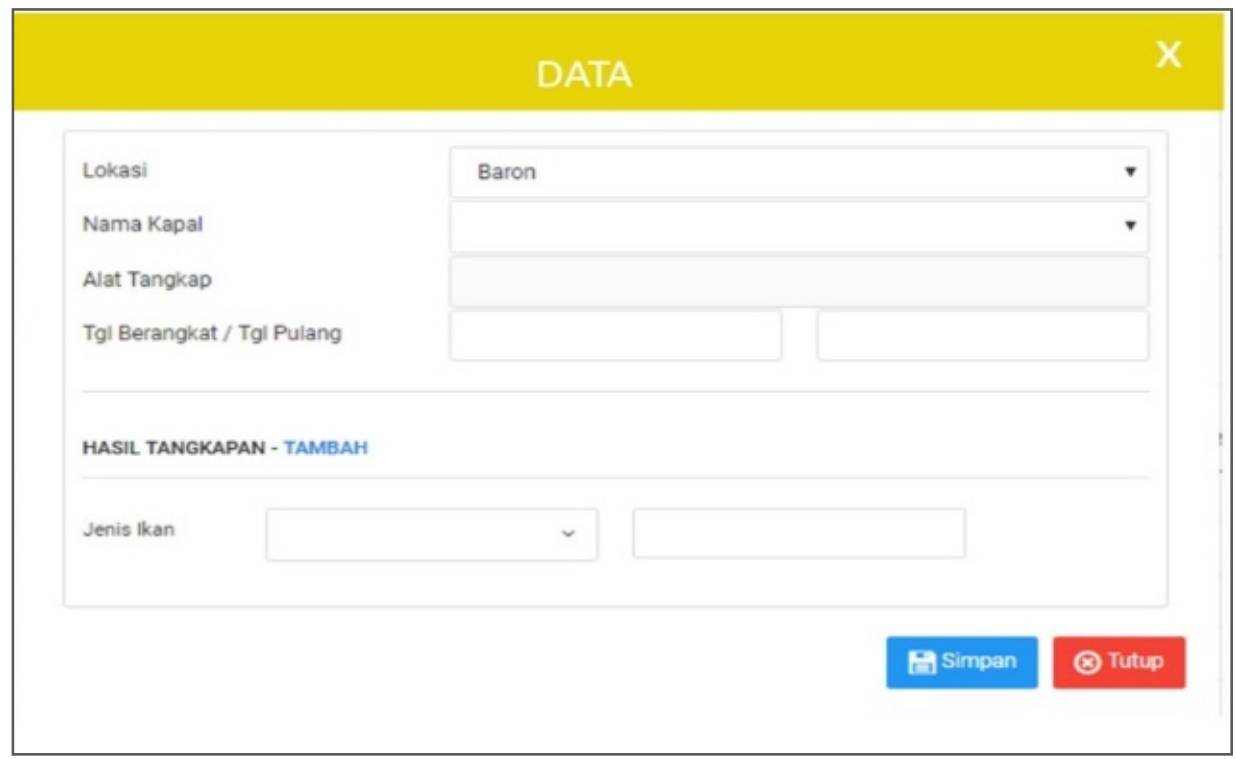

(b) Fasilitas input data

Gambar 1 Menu Log Masuk dan Input Data pada SIM Perikanan Tangkap DIY 
Basis data lingkungan perairan ini merupakan bagian pertama dari 'Sistem Basis Perikanan Tangkap D.I. Yogyakarta'. Basis data ini disajikan pada menu utama lingkungan yang terbagi dalam empat menu, yaitu menu klorofil-a, menu suhu permukaan laut (SPL), menu terumbu karang, dan menu oseanografi perairan D.I. Yogyakarta. Menu tersebut akan memberi informasi terkait dinamika lingkungan perairan, di mana nelayan D.I. Yogyakarta melakukan operasi penangkapan ikan. Informasi tersebut dibutuhkan untuk mendukung produksi ikan, terutama dalam penentuan musim ikan dan daerah penangkapan ikan (DPI) yang potensial. Menu terumbu karang memberi informasi tambahan dalam penangkapan ikan demersal terutama yang berhabitat di karang. Tutupan karang yang tinggi (> 60 \%) mempercepat perkembangan dan dapat menjaga habitat alami ikan (LIPI 2015, Mustaruddin et al. 2017)). Gambar 2 menyajikan contoh tampilan data untuk setiap menu pada menu utama lingkungan perairan.

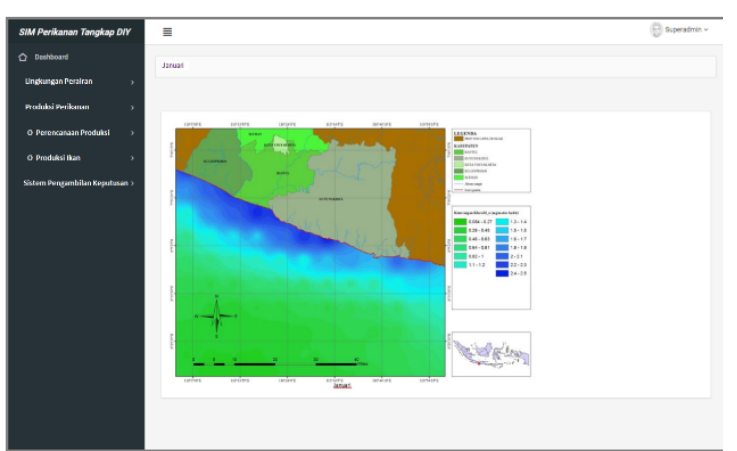

(a) Menu klorofil (sub menu bulan Januari)

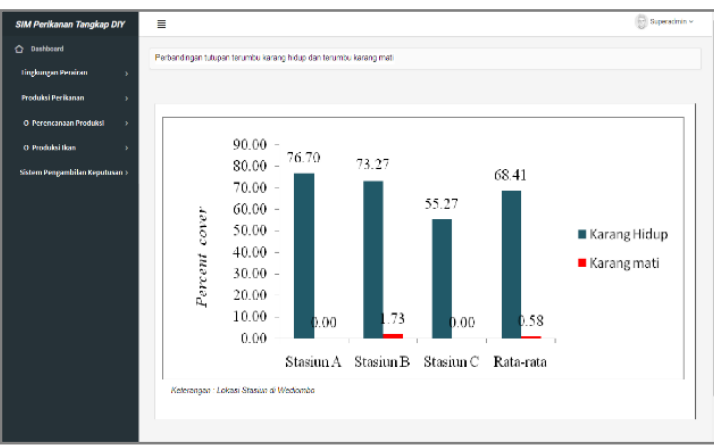

(c) Menu terumbu karang (sub menu tutupan karang)

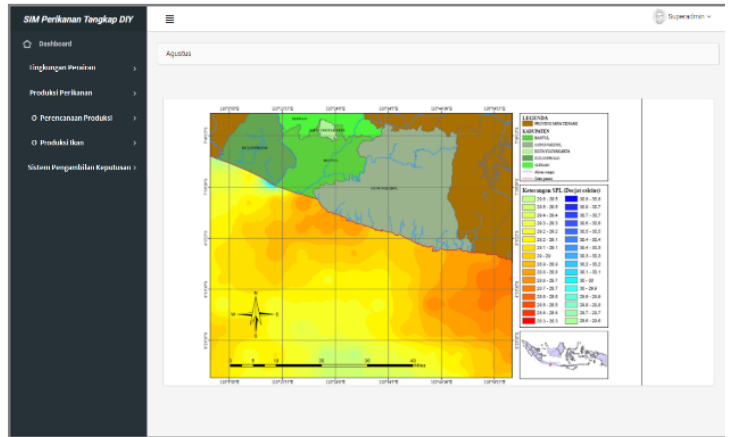

(b) Menu SPL (sub menu bulan Agustus)

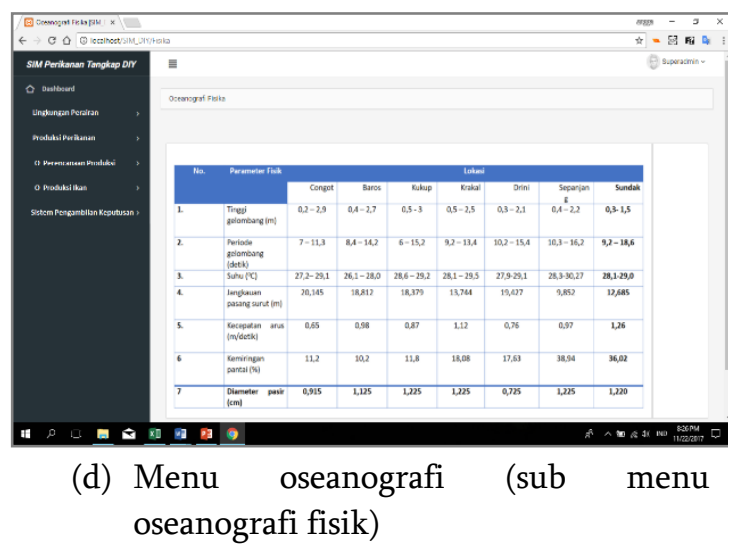

Gambar 2 Menu Utama Lingkungan Perairan

Untuk memperkaya data pada menu utama lingkungan, maka setiap menu penyusun dikembangkan dalam beberapa sub menu. Untuk menu klorofil-a misalnya, menyajikan data klorofila bersifat bulanan yang disajikan pada sub menu klorofil-a bulanan (Gambar 2.a). Hal yang sama juga untuk menu SPL, misalnya pada Gambar 2.b menyajikan data SPL bulan Agustus 2017. Data citra satelit sebenarnya dapat tersedia dalam skala harian atau mingguan, namun supaya dinamika lebih terlihat dan mudah menginterpretasikannya (PUSHIDROSAL 2017, Jalali et al. 2015), maka disajikan dalam skala bulanan. Untuk menu terumbu karang terbagi dalam sub menu tutupan karang (Gambar 2.c.) dan sub menu biota laut asosiasi terumbu karang. Sedangkan menu oseanografi, dikembangkan lanjut menjadi sub menu oseanografi kimia, sub menu oseanografi fisika (Gambar 2.d), dan sub menu oseanografi biologi.

Ketersediaan data yang cukup tersebut akan memberikan informasi akurat bagi menu utama sistem pengambilan keputusan dalam analisis/perhitungan misalnya terkait musim ikan, DPI potensial, dan produksinya. Data tersebut akan mewakili setiap peubah/komponen pada sistem informasi, dan dinamikanya akan merepresentasikan perubahan-perubahan yang terjadi secara nyata pada kegiatan 
perikanan tangkap D.I. Yogyakarta (BAPPEDA DIY 2019, Partosuwirjo et al. 2008). Data ini diperoleh dari pelabuhan/pangkalan pendaratan ikan yang tersebar di sepanjang pesisir D.I. Yogyakarta. Operasi penangkapan yang dilakukan para nelayan D.I. Yogyakarta menjadi sumber penting data tersebut yang selanjutnya dicatat dan di-input kembali ke dalam 'Sistem Informasi Perikanan Tangkap'. Input data tersebut kemudian memperbaharui informasi pada menu jumlah produksi, menu nilai produksi, menu kinerja usaha penangkapan ikan, dan lainnya. Dalam operasionalisasinya, input data perlu dilakukan oleh operator khusus yang secara terus menerus mengikuti perkembangan data perikanan tangkap dari waktu ke waktu (O'Brien dan Marakas 2011, Menard et al. 2002). Hal ini penting agar pada saat data tersebut dan hasil analisisnya digunakan dapat memberi informasi yang akurat. Bentuk penggunaan lainnya dari menu utama lingkungan perairan ini adalah untuk penentuan potensi upwelling dan sebaran musim ikan. Kedua hal ini dibahas lebih lanjut pada bagian berikut terkait basis data produksi ikan.

\section{Basis Data Produksi Perikanan}

Basis data produksi disajikan pada menu utama produksi perikanan yang memuat : (a) empat menu terkait perencanaan produksi, seperti menu DPI, menu upwelling, menu potensi SDI, menu musim ikan, dan menu sarana penangkapan ikan, dan (b) tiga menu terkait operasionalisasi produksi ikan, seperti menu produksi ikan, menu nilai produksi, dan menu kinerja usaha penangkapan ikan. Gambar 3 menyajikan contoh tampilan data yang berkaitan dengan menu-menu perencanaan produksi.

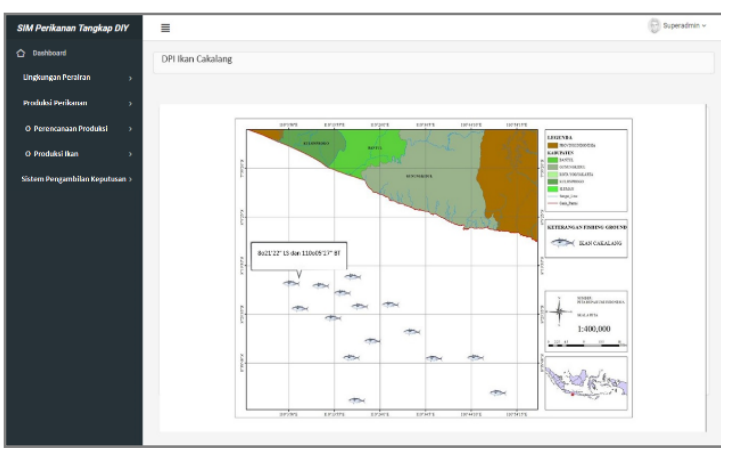

(a) Menu DPI (sub menu DPI cakalang)

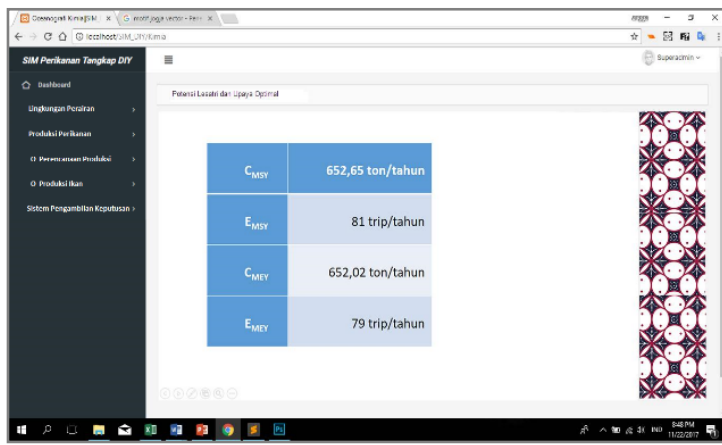

(c) Menu potensi SDI

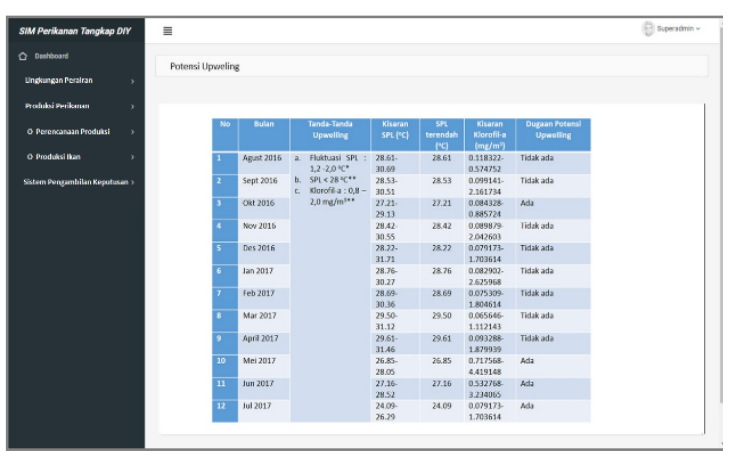

(b) Menu potensi upwelling

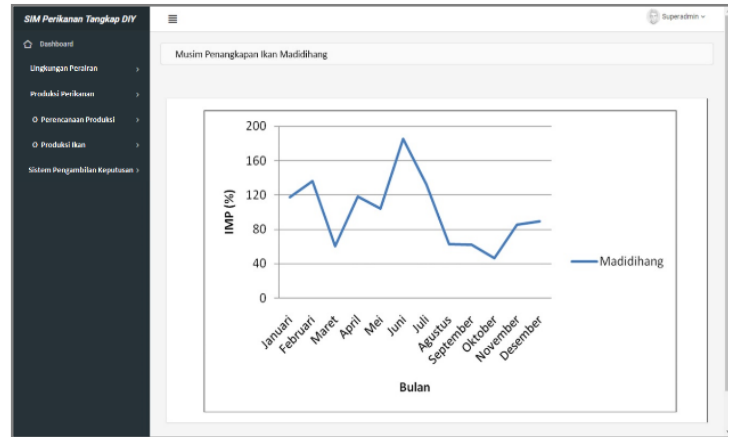

(d) Menu musim ikan (sub menu musim madidihang)

Gambar 3 Menu Utama Produksi Perikanan (Tahap Perencanaan Produksi)

Pengembangan basis data/menu utama produksi perikanan ini dilakukan dengan merinci beberapa menu yang mempunyai data detail menjadi beberapa sub menu, misalnya menu DPI dan menu musim ikan. Pada menu DPI, sub menu dikembangkan berdasarkan jenis ikan potensial di perairan D.I Yogyakarta, seperti sub menu DPI madidihang, sub menu DPI cakalang (Gambar 3.a), sub menu DPI layang, sub menu DPI udang, dan lain-lain. Menu musim ikan juga dikembangkan menjadi beberapa sub menu dengan cara yang sama. Informasi yang ditampilkan pada menu DPI dan menu 
musim ikan berasal dari hasil analisis data pada menu utama lingkungan perairan terutama data klorofil-a dan SPL yang pengolahannya dilakukan pada menu utama SPK. Dengan demikian, informasi pada menu DPI dan menu musim ikan ini merupakan informasi final yang dapat digunakan langsung dalam operasi penangkapan ikan (Batista et al. 2015, Rahmi et al. 2013).

Pada menu utama produksi perikanan, juga terdapat menu jumlah produksi ikan, menu nilai produksi ikan (Gambar 4), dan menu kinerja usaha penangkapan ikan. Bersama dengan menu potensi DPI dan musim ikan, ketiga menu ini akan lebih banyak memuat hasil analisis/perhitungan yang dilakukan oleh sistem pengambilan keputusan pada sistem informasi ini.

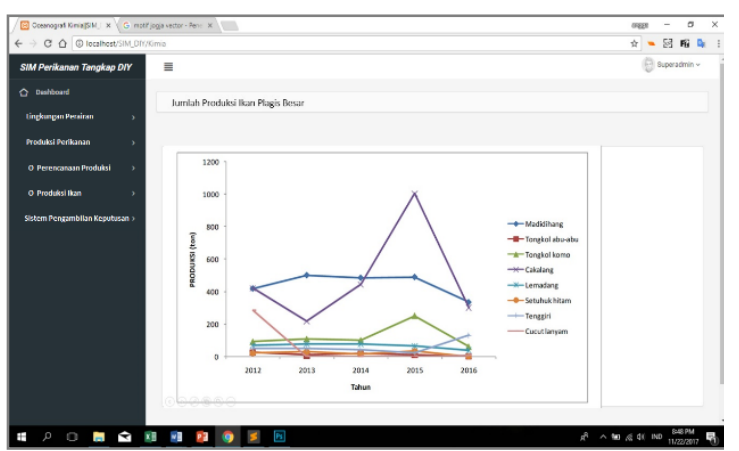

(a) Menu jumlah produksi ikan (sub jumlah produksi ikan pelagis besar)

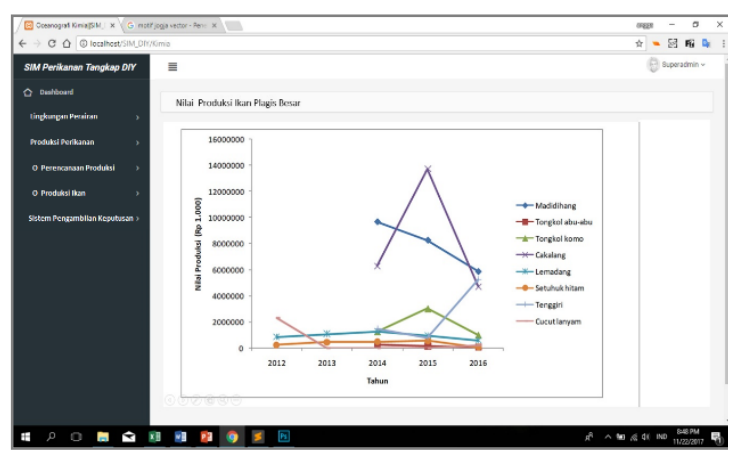

(b) Menu nilai produksi ikan (sub nilai produksi ikan pelagis besar)

Gambar 4 Menu Utama Produksi Perikanan (Tahap Produksi Ikan)

Untuk menu jumlah produksi ikan, pengembangan sub menunya dilakukan berdasarkan kelompok ikan, yaitu ikan pelagis besar (Gambar 4.a), ikan pelagis kecil, ikan demersal, serta udang dan biota laut lainnya. Hal yang sama juga untuk menu nilai produksi ikan dengan ditambah sub menu harga ikan. Adapun informasi jumlah produksi dan nilai produksi per jenis ikan, diintegrasikan pada sub menu kelompok ikan yang bersesuaian, misalnya jumlah produksi ikan madidihang dan ikan cakalang yang merupakan kelompok ikan pelagis besar tersajikan pada sub menu jumlah produksi ikan pelagis besar (Gambar 3.a). Hal ini dilakukan dalam rangka pengefektifan dan integrasi informasi. O'Brien dan Marakas (2011) menyatakan bahwa informasi yang akurat dan lengkap bisa tidak berguna bila banyak redundance dan tidak disajikan secara terintegrasi. Sedangkan menurut Batstone dan Sharp (2003) dan Hinds dan Piche (1998), informasi penting akan menjadi kabur maknanya bila tidak disajikan secara memadai berdasarkan keumuman display kepada user dan publik.

\section{Sistem Pengambilan Keputusan}

Sistem pengambilan keputusan (SPK) merupakan menu utama yang memuat tentang berbagai analisis/perhitungan berdasarkan data terbaru, sehingga membantu pengambilan kebijakan di bidang perikanan tangkap, terutama terkait penangkapan ikan. Mekanisme kerja dari menu utama ini adalah melakukan analisis dan update hasil analisis berdasarkan data ter-input pada dua menu utama lainnya (basis data lingkungan dan basis data produksi perikanan), selanjutnya hasil analisis terbaru ditampilkan pada menu yang bersesuaian di menu utama pengirim, misalnya seperti sudah ditunjukkan pada Gambar 2 dan Gambar 3. Gambar 5 menyajikan beberapa tampilan menu analisis/perhitungan yang mendukung kerja menu utama SPK. 

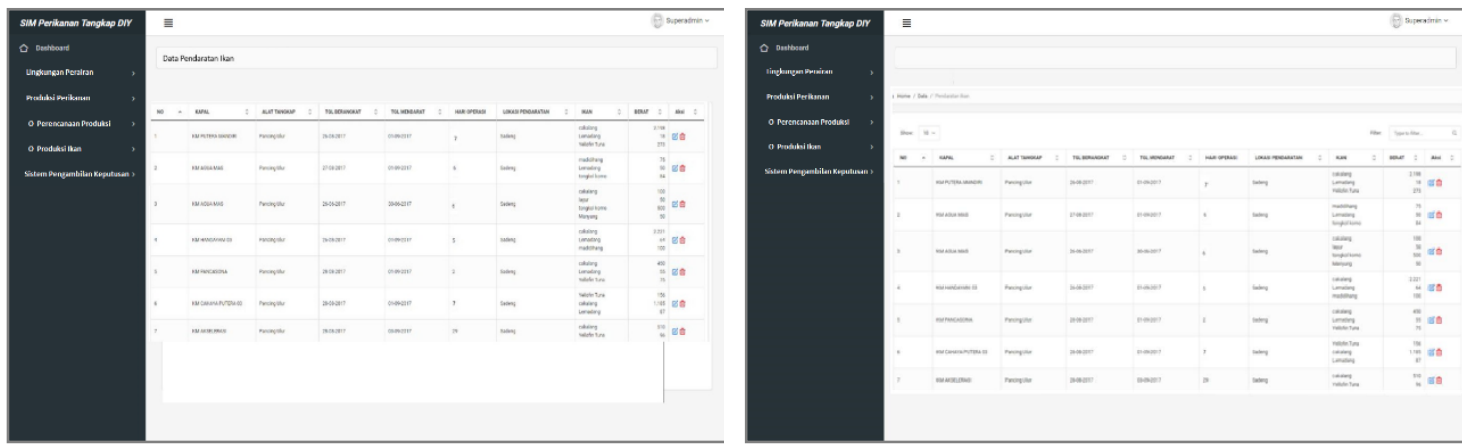

(a) Menu perhitungan potensi SDI
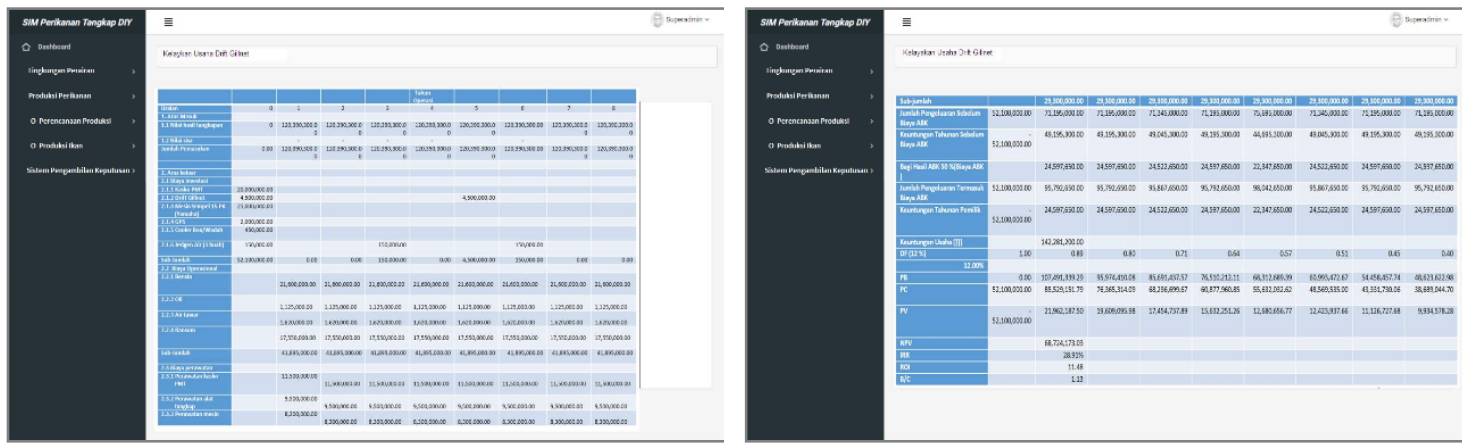

(b) Menu analisis kelayakan usaha

\section{Gambar 5 Menu Utama Sistem Pengambilan Keputusan}

Analisis/perhitungan pada Gambar 4, akan terus berulang selama ada data baru yang dikirim oleh basis data lingkungan dan basis data produksi perikanan. O'Brien dan Marakas (2011) dan Chavance et al. (2007) menyatakan bahwa menu SPK dirancang untuk bekerja otomatis atau minimal dengan perintah refresh sederhana dapat memperbaharui hasil analisis data. Menu analisis lainnya yang terintegrasi pada menu utama SPK ini adalah menu analisis moving average untuk menganalisis perilaku musim ikan dan menu analisis pemetaan untuk penentuan daerah penangkapan ikan beberapa jenis ikan yang dianggap potensial, seperti ikan madidihang, tongkol, cakalang, layur, layang, dan lainnya. Menurut DKP DIY (2019), ikan madidihang merupakan jenis hasil tangkapan utama dari kelompok tuna di D.I. Yogyakarta dan banyak investor yang berinvestasi pada bisnis ikan ini, baik dalam penangkapan, pengolahan, maupun pemasarannya. Kontribusi kelompok ikan terhadap produksi perikanan tangkap pada tahun 2018 mencapai 371,66 ton, dan rata-rata dalam 7 tahun terakhir (20122018) sekitar 427,32 ton/tahun. Produksi ikan tongkol dan cakalang tidak terlalu besar, tetapi cukup siginifikan di D.I Yogyakarta dan ditangkap dengan alat tangkap yang relatif sama dengan madidihang (BAPPEDA DIY 2019, Gephart et al. 2017). Sedangkan udang, yang potensial di D.I. Yogyakarta adalah udang putih/jerbung, dengan jumlah produksi mencapai rata-rata 27,2 ton per tahun (DKP DIY 2019).

Pada menu analisis kelayakan usaha, data penting yang dibutuhkan dalam analisis adalah kebutuhan investasi, perbekalan melaut, jumlah ikan hasil tangkapan, dan harga. Data ini didapat dari nelayan yang beraktivitas di pelabuhan/pangkalan pendaratan ikan D.I. Yogyakarta. Menurut Sumaila et al. (2016) dan Chavance et al. (2007) informasi kelayakan dan peluang usaha menjadi perhatian penting bagi investor untuk berinvestasi pada suatu usaha perikanan, karena memberi gambaran nyata dari kesuksesan penanaman modal yang dilakukannya. Sedangkan menurut Batista et al. (2015) dan Prabowo et al. (2013), kelayakan usaha dapat menjadi acuan bagi pembinaan nelayan dalam pengelolaan usahanya, sekaligus rekomendasi kebijakan bagi pengembangan investasi perikanan tangkap secara jangka panjang. Informasi kelayakan usaha yang ter-update lebih dipercaya investor karena mengukur kinerja finansial dari suatu kegiatan penangkapan secara real time dengan memperhatikan pola musim di sepanjang tahun. Hasil analisis pada menu utama SPK ini, dapat 
membantu menyajikan informasi tersebut, di mana data kegiatan penangkapan dapat di-input setiap waktu, dan hasil analisisnya juga dapat langsung ditampilkan.

Hal yang sama juga untuk informasi musim ikan dan daerah penangkapan ikan yang potensial. Model moving average yang diintegrasikan pada SIM Perikanan Tangkap DIY ini, akan memanfaatkan update data terkait seperti jumlah hasil tangkapan, trip melaut, dan jumlah kapal yang beroperasi untuk menangkap ikan tertentu menjadi informasi musim dari keberadaan ikan tersebut. Hal ini akan sangat membantu bagi nelayan dan investor di bidang perikanan tangkap untuk menentukan waktu operasi penangkapan ikan yang tepat. PUSHIDROSAL (2017) dan Maina et al. (2016) menyatakan bahwa di samping dapat meningkatkan jumlah hasil tangkapan ikan, informasi musim ikan juga dapat mengefisienkan biaya operasi dan perbekalan melaut. Sedangkan menurut Merkel dan Madsen (2019), Jalali et al. (2015), dan Hall dan Close (2007), informasi musim ikan yang didukung oleh hasil pendugaan daerah penangkapannya dapat meningkat kinerja usaha penangkapan 2-3 kali dari biasanya, dan ini banyak dimanfaatkan oleh pelaku perikanan tangkap di beberapa negara Eropa dan Afrika Barat. Pada SIM Perikanan Tangkap DIY ini, daerah penangkapan potensial dapat ditentukan berdasarkan update data terkait seperti data klorofil-a dan suhu permukaan laut (SPL), di mana menu utama SPK akan mem-ploting data tersebut dan setelah diperbandingkan dengan kondisi ideal, didapatkan sebaran daerah penangkapan ikan yang baru.

Untuk meningkat kinerja sistem informasi ini termasuk dalam memeriksa hasil-hasil analisisnya, maka dilakukan dua jenis pemeriksaan/evaluasi, yaitu validasi data dan evaluasi sistem. O'Brien dan Marakas (2011) menyatakan bahwa pemeriksaan dari dua sisi (data dan sistem) penting dilakukan untuk meminimalisir bias dan tingkat kesalahan sistem yang memuat banyak metode analisis. Sedangkan menurut Gephart et al. (2017), sistem yang tervalidasi dengan baik dapat menyajikan hasil analisis data perikanan yang akurat terutama yang terkait dengan trend produksi ikan dan potensi ekonominya. Validasi data pada SIM Perikanan Tangkap DIY ini dilaksanakan setiap kali meng-input data yang mencakup rasionalitas data, sumber data (pelabuhan/pangkalan pendaratan ikan), dan frekuensi penerimaan data. Sedangkan evaluasi sistem dilakukan setiap periode pelaporan (bulanan dan tahunan) yang mencakup pemeriksaan struktur hasil analisis dari suatu metode analisis/perhitungan dalam SPK, pemeriksaan besaran/satuan, dan pemeriksaan integrasi menu-menu pada sistem informasi. Jenis validasi dan pemeriksaan seperti ini diyakini dapat meningkatkan kinerja sistem informasi, sehingga mendukung pengambilan keputusan perikanan tangkap yang kompleks, melibatkan banyak pihak, dan komponennya banyak bergantung pada alam (Chuenpagdee et al. 2019). Sedangkan menurut Chavance et al. (2007) dan Mustaruddin dan Wiyono (2020), keakuratan SPK dalam pengambilan keputusan terkait potensi produksi, jenis-jenis ikan yang sedang musim, DPI potensial, dan peluang usahanya dapat mendorong percepatan investasi perikanan tangkap. Hal ini karena investor mendapat informasi yang valid dan lengkap dalam perencanaan penanaman modal pada kegiatan penangkapan ikan dan usaha pendukungnya.

\section{KESIMPULAN DAN SARAN}

Sistem informasi yang telah dirancang bernama 'Sistem Informasi Manajemen Perikanan Tangkap D.I. Yogyakarta' (SIM Perikanan Tangkap DIY). Hasil rancangan sistem informasi memuat dua sistem basis data dan satu sistem pengambilan keputusan (SPK). Sistem basis data tersebut adalah basis data lingkungan perairan dan basis data produksi perikanan yang keduanya berfungsi sebagai penyimpan dan menyuplai data untuk pengambilan keputusan penangkapan ikan dan pendukungnya. Menu-menu penting yang telah diintegrasikan pada sistem basis data lingkungan perairan di antaranya menu klorofil, SPL, terumbu karang, dan oseanografi perairan, sedangkan pada sistem basis data produksi perikanan di antaranya menu DPI, potensi upwelling, potensi SDI, musim ikan, jumlah produksi, nilai produksi, dan kinerja usaha penangkapan ikan. SPK dirancang sedemikian rupa sehingga dapat mengolah data penting pada dua menu utama sebelumnya. SPK ini mengkoneksikan analisis/ 
perhitungan terkait perikanan tangkap seperti analisis potensi SDI, analisis moving average, analisis musim, dan analisis kelayakan usaha.

\section{UCAPAN TERIMA KASIH}

Ucapan terima kasih disampaikan kepada staf Dinas Kelautan dan Perikanan D.I. Yogyakarta yang telah banyak membantu dalam pelaksanaan penelitian ini.

\section{DAFTAR PUSTAKA}

BAPPEDA Daerah Istimewa Yogyakarta. 2019. Aplikasi Dataku Daerah Istimewa Yogyakarta [internet]. [diacu 2019 Desember 21]. Tersedia dari: http://bappeda.jogjaprov.go.id/ dataku/ data_dasar/cetak/132-perikanan-tangkap-laut.

Batista MI, Horta e Costa B, Gonçalves L, Henriques M, Erzini K, Caselle JE, Gonçalves EJ, Cabral HN. 2015. Assessment of catches, landings and fishing effort as useful tools for MPA management. Journal of Fisheries Research. 172(1): 197-208. https://doi.org/10.1016/j.fishres.2015.07.020.

Batstone CJ, Sharp BMH. 2003. Minimum information management systems and ITQ fisheries management. Journal of Environmental Economics and Management. 45(2): 492-504.

Chavance P, Morand P, Thibaut L, Moctar B. 2007. Challenges and difficulties of cooperation between fisheries information systems-Experiences in six West African developing countries. Ocean dan Coastal Management. 50(9): 713-731.

Chuenpagdee R, Rocklin D, Bishop D, Hynes M, Greene R, Miguel R.Lorenzi, Devillers D. 2019. The global information system on small-scale fisheries (ISSF): A crowdsourced knowledge platform. Marine Policy. 101(1): 158-166.

[DKP] Dinas Kelautan dan Perikanan Daerah Istimewa Yogyakarta. 2018. Laporan Kinerja Sektor Perikanan dan Kelautan Daerah Istimewa Yogyakarta. Yogyakarta (ID): Dinas Kelautan dan Perikanan Daerah Istimewa Yogyakarta.

Gephart GA, Deutsch L, Pace MM, Troellb M, Seekellde DA. 2017. Shocks to fish production: Identification, trends, and consequences. Global Environmental Change. 42(1): 24-32. https://doi.org/10.1016/j.gloenvcha.2016.11.003.

Hall GB, Close CH. 2007. Local knowledge assessment for a small-scale fishery using geographic information systems. Fisheries Research. 83(1): 11-22.

Hinds LO, Piché R. 1998. Oceans, Marine Affairs, and Fisheries (OMAF) database emphasis: SouthSouth network module. Marine Policy. 22(6): 537-538.

Jalali MA, Ierodiaconou D, Monk J, Gorfine H, Rattray A. 2015. Predictive mapping of abalone fishing grounds using remotely-sensed LiDAR and commercial catch data. Journal of Fisheries Research. 169(1): 26-36.

Lembaga Ilmu Pengetahuan Indonesia (LIPI). 2015. Sumberdaya Laut di Perairan Pesisir, Gunungkidul, Yogyakarta. Jakarta (ID): LIPI.

Maina I, Kavadas S, Katsanevakis S, Somarakis S, Tserpes G, Georgakarakos S. 2016. A methodological approach to identify fishing grounds: A case study on Greek trawlers. Journal of Fisheries Research. 183(1): 326-339.

Mayes TR, Shank M. 2006. Financial Analysis with Microsoft Excel 4th Edition. Nashville (USA): South-Western College Pub. 
Ménard F, Nordström V, Hoepffner J, Konan J. 2002. 20 A database for the trawl fisheries of Côte d'Ivoire: Structure and use. Large Marine Ecosystems. 11(1): 275-287.

Merkel A, Madsen SKS. 2019. Lessons from port sector regulatory reforms in Denmark: An analysis of port governance and institutional structure outcomes. Transport Policy. 78(1): 31-41.

Mustaruddin dan Wiyono ES. 2020. Prospek Usaha dan Strategi Pengembangan Perikanan Tangkap di PPP Sadeng, Yogyakarta. Prosiding Seminar Perikanan Tangkap ke-8, 17 Oktober 2019: 59-73.

Mustaruddin, Baskoro MS, Kandi O, Nasruddin. 2017. Environmental and technical approach in the selection of fishing gear featured in WPP 571 Aceh. IJSBAR. 31(3): 44-53.

O’Brien JA, Marakas GM. 2011. Management Information System : A Managerial End User Perspective. New York (USA): The McGraw-Hill Companies Inc.

Partosuwirjo M, Haluan J, Baskoro MS, Soemokaryo S. 2008. Model Pengembangan Usaha Perikanan Tangkap di Daerah Istimewa Yogyakarta. Jurnal Manajemen dan Agribisnis. 5(1): 23-32.

Prabowo, Wiyono ES, Haluan J, Iskandar BH. 2013. Kinerja pembiayaan perikanan skala kecil di Kota Tegal, Provinsi Jawa Tengah. Marine Fisheries. 4(1): 1-9.

Pusat Hidrografi dan Oseanografi TNI Angkatan Laut (PUSHIDROSAL). 2017. Pemetaan Kondisi Laut dan Oseanografi Perairan Selatan Jawa. Jakarta (ID): PUSHIDROSAL.

Rahmi TA, Nurani, TW, Wahyuningrum PI. 2013. Usaha Perikanan Tangkap Skala Kecil di Sadeng, Provinsi Daerah Istimewa Yogyakarta. Jurnal Amanisal. 2(2): 40-45.

Sumaila UR, Bellmann C, Tipping A. 2016. Fishing for the future: An overview of challenges and $\begin{array}{lllll}\text { opportunities. Journal of Marine Policy. } & \text { 69(1): 173-180. }\end{array}$ https://doi.org/10.1016/j.marpol.2016.01.003. 